TRAUMA CARE

\title{
Trauma quality improvement: The Pietermaritzburg Metropolitan Trauma Service experience with the development of a comprehensive structure to facilitate quality improvement in rural trauma and acute care in KwaZulu-Natal, South Africa
}

\section{L Clarke}

Before 2006, Damian Clarke was a surgeon at Durban's South Beach, also known as Addington Hospital. Since fleeing the ongoing attempts to gentrify and 'Disneyfy' the beachfront, he has tried to reinvent himself as a faux Midlands farmer and member of the landed gentry in the misty foothills of the Drakensberg.

Corresponding author: D L Clarke (damianclar@gmail.com)

Improving the delivery of efficient and effective surgical care in rural South Africa is a mammoth task bedevilled by conflict between the stakeholders, who include rural doctors, surgeons, ancillary staff, researchers, educators and administrators. Management training is not part of most medical school curricula, yet as they progress in their careers, many clinicians are required to manage a healthcare system and find the shift from caring for individual patients to managing a complex system difficult. Conflict arises when management-type interventions are imposed in a top-down manner on surgical staff suspicious of an unfamiliar field of study. Another area of conflict concerns the place of surgical research. Researchers are often accused of not being sufficiently focused on or concerned about the tasks of service delivery. This article provides an overview of management theory and describes a comprehensive management structure that integrates a model for healthcare systems with a strategic planning process, strategic planning tools and appropriate quality metrics, and shows how the Pietermaritzburg Metropolitan Trauma Service in KwaZulu-Natal Province, South Africa, successfully used this structure to facilitate and contextualise a diverse number of quality improvement programmes and research initiatives in the realm of rural acute surgery and trauma. We have found this structure to be useful, and hope that it may be applied to other acute healthcare systems.

S Afr Med J 2015;105(2):92-95. DOI:10.7196/SAMJ.8792

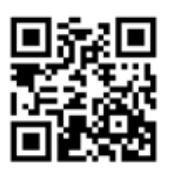

The strategic planning process and healthcare systems

Strategic planning is a systematic process designed to assist organisational decision-making by taking account of the microenvironment(s) within an organisation, as well as the macroenvironment in which the organisation exists. ${ }^{[1-5]}$ Healthcare systems are complex and tightly coupled. Strategic planning within such a system, without an overarching framework to provide a structure for quality improvement programmes, risks becoming ad hoc, haphazard, ineffectual and even counterproductive. The strategic planning process must identify the organisation's vision and mission or the system's aims and objectives. The mission statement explains the reasons for the healthcare system's existence. The vision statement identifies a potential more ideal 'future state' that the system aspires to achieve. Situational analysis follows and analyses the external environment to identify threats and opportunities, then looks inwards to assess the organisation's resources and capabilities. ${ }^{[1-6]}$

The stage of synthesis follows, in which the strategic plan is crafted. The plan must then be implemented, and after that outcomes must be audited. There are a number of generic strategic planning tools that are of relevance to developing a structured systemic approach to quality improvement programmes. These include the SWOT analysis, the balanced scorecard, and strategic drift and gap analysis.

\section{SWOT}

This acronym stands for Strengths, Weaknesses, Opportunities and Threats (SWOT) and identifies internal strengths and weaknesses, and threats and opportunities in the external environment, that may affect the organisation.

\section{The balanced scorecard}

The balanced scorecard is a forward-looking management system that views the organisation from four perspectives, namely learning and growth, process, the customer point of view, and results.

\section{Strategic drift and gap analysis}

The final outcome of a strategic plan is a result of the interaction of the external environment and three internal factors, namely the plan, the leadership and the culture of the organisation. A gap analysis model helps identify reasons for the strategic gap.

\section{A healthcare system model}

There is a well-established model for thinking about healthcare systems (Table 1) that breaks a healthcare system down into inputs, 
Table 1. The components of a healthcare system (Donabedian ${ }^{[5]}$ )

\begin{tabular}{|c|c|c|}
\hline Inputs & Process & Outcome \\
\hline Macroeducational programmes & Application process & Newly qualified staff \\
\hline University funding & Admission process & Doctor/nurse/paramedic to patient ratios \\
\hline Nursing colleges & Academic support for disadvantaged students & \\
\hline Ambulance training colleges & Type of education & \\
\hline \multirow[t]{2}{*}{ Microeducational programmes at hospital level } & Staff attending & Improvement in patient care \\
\hline & Staff completing course & Compliance with guidelines \\
\hline \multirow[t]{2}{*}{ Hospital morbidity and mortality meetings } & Staff attending & Decreased rates of adverse events \\
\hline & Cases discussed & \\
\hline CT scanner & Call list & Patients scanned \\
\hline \multirow[t]{2}{*}{ Radiology staffing } & Protocols for use & Treatment influenced \\
\hline & Waiting time & Accuracy of reporting \\
\hline ICU beds & Triage policy & Patients treated \\
\hline \multirow[t]{3}{*}{ ICU staffing } & Referral system & Mortality rates \\
\hline & & Length of stay \\
\hline & & Readmission rate \\
\hline
\end{tabular}

process and outcome. ${ }^{[4,5]}$ Table 1 attempts to give examples of the various constituents of a healthcare system and to categorise them according to which component they reflect. The system comprises two variables and a product of those two variables. Healthcare outcomes are a direct product of the interaction between inputs and processes. The only components of the healthcare system that planners can directly influence are the inputs and the processes. The relationship between inputs and process is not linear, and increasing inputs without altering process will not necessarily improve outputs. Conversely, improving the process of care without increasing the resources available may result in a dramatic improvement in outcomes.

\section{Metrics to measure outcomes of a healthcare system}

A good quality indicator provides a platform to improve processes and outcomes and can be classified according to type or according to which component of a healthcare system it measures. Table 2 attempts to contextualise the type of quality indicators against the component of the healthcare system being analysed. ${ }^{[5,6]}$

\section{A comprehensive strategic planning structure for healthcare systems}

I have developed an overarching structure or grid (Table 3 ) that allows planners to contextualise the strategic planning process against the various components of the healthcare system, to plan accordingly, and to evaluate improvements over time. It integrates the planning process, the components of the system, and quality metrics. The structure comprises a composite grid with an $x$ axis and a $y$ axis. Along the $y$ axis are the components of the strategic planning process (analysis, synthesis and implementation), and along the $x$ axis are the three components of a healthcare system (inputs, processes, outcomes). Within each cell of the grid there is room for the appropriate strategic planning tool as well as the specific quality improvement intervention, and for the appropriate metric. The model allows a planner to identify each metric according to its role in the strategic planning process and according to the component of the system it is measuring. Above and below the grid are columns for the mission and vision of the organisation. These should inform each grid. Table 3 attempts to
Table 2. Examples of types of indicators available

\begin{tabular}{ll}
\hline Generic and disease-specific indicators & Injury per capita \\
Rate-based indicators & Caseload \\
Sentinel indicators & Wrong-site surgery \\
Input/structural indicators & Ambulance-to-patient ratio \\
Process indicators & Time to theatre \\
& Time till admission \\
Outcome indicators & Mortality rates \\
& Length of stay
\end{tabular}

show how the grid could be used to situate each tool, intervention or metric according to the stage of the strategic planning process and the component of the healthcare system it is addressing. Planners can situate each planning tool in its appropriate grid. Each proposed intervention can also be placed in a grid according to whichever component of the system it is intended to address. Table 4 illustrates how such a structure may be used in practice to contextualise data from a number of sources in rural trauma and acute care.

\section{Applying the grid to the Pietermaritzburg Metropolitan Trauma Service (PMTS)}

Since its inception in 2006, the PMTS in KwaZulu-Natal Province, South Africa (SA), has run a research and a quality improvement programme aimed at uplifting trauma care at Edendale Hospital and in the rural Sisonke health district. This programme is a multifaceted one, as it is obvious that no single intervention will address all the deficits in trauma and acute surgical care in our system. The grid structure has helped to contextualise all programmes within an overarching structure. This is represented in Table 4, which places a number of research projects into context. Commencing by measuring the resources available to deal with trauma and the burden of disease, ${ }^{[7]} \mathrm{I}$ then adopted a number of theoretical constructs, taken from fields outside surgery, and used them to both measure quality of care and to inform potential interventions. These theoretical constructs included error theory and the idea of developing a suitable quality 
Table 3. Comprehensive structure for a quality improvement programme looking at improving the quality of care of acute trauma patients in a rural health district in SA

\begin{tabular}{|c|c|c|c|c|}
\hline Vision $^{*}$ & Quality metric & Quality metric & Quality metric & \\
\hline Mission $^{\dagger}$ & Inputs & Processes & $\begin{array}{l}\text { Outcomes cannot be directly } \\
\text { targeted but must be audited }\end{array}$ & \\
\hline $\begin{array}{l}\text { Analysis } \\
\text { SWOT } \\
\text { Strategic drift } \\
\text { Balanced scorecard }\end{array}$ & $\begin{array}{l}\text { What is the load of trauma? } \\
\text { What is the capacity of the rural } \\
\text { hospitals to deal with this load? } \\
\text { Can we develop new metrics? } \\
\text { Can we use new constructs to } \\
\text { help us? }\end{array}$ & $\begin{array}{l}\text { What is the delay from injury to } \\
\text { arrival at the district hospital? } \\
\text { What is the delay from district } \\
\text { hospital to regional hospital? } \\
\text { Quality of documentation } \\
\text { Quality of care }\end{array}$ & $\begin{array}{l}\text { What is the mortality rate } \\
\text { compared with elsewhere? } \\
\text { What is the error rate compared } \\
\text { with elsewhere? } \\
\text { What is the length of stay? } \\
\text { What is the cost? }\end{array}$ & Metrics \\
\hline $\begin{array}{l}\text { Synthesis and } \\
\text { implementation } \\
\text { Generic quality } \\
\text { improvement } \\
\text { strategies } \\
\text { Increase resources } \\
\text { Improve process }\end{array}$ & $\begin{array}{l}\text { Can we decrease the load? } \\
\text { (injury prevention) } \\
\text { Can we increase the number of } \\
\text { staff available? } \\
\text { Can we improve the quality } \\
\text { of the staff available with } \\
\text { educational programmes? } \\
\text { Can we improve monitoring } \\
\text { systems? } \\
\text { Will better reporting and } \\
\text { feedback to staff improve care? }\end{array}$ & $\begin{array}{l}\text { Should we change the referral } \\
\text { patterns? } \\
\text { Should specific trauma patients } \\
\text { bypass the small district } \\
\text { hospital? } \\
\text { Can we change the way we } \\
\text { deliver care? } \\
\text { Restructuring morbidity and } \\
\text { mortality meetings }\end{array}$ & $\begin{array}{l}\text { Have we improved the } \\
\text { mortality rate? } \\
\text { Have we reduced the error rate? } \\
\text { Have we reduced the length } \\
\text { of stay? } \\
\text { Have we improved cost? }\end{array}$ & $\begin{array}{l}\text { Develop } \\
\text { targeted quality } \\
\text { improvement } \\
\text { programmes }\end{array}$ \\
\hline Vision & Quality metric & Quality metric & Quality metric & \\
\hline
\end{tabular}

marker for surgery. ${ }^{[8,9]}$ These systems were used to assess the quality of care in the area. ${ }^{[10-15]}$

Once this situational analysis was done, I moved on to the stage of synthesis of strategies and interventions, introducing educational programmes and refinement of morbidity and mortality meetings with the intention of driving quality improvement; ${ }^{[16,17]}$ a number of innovative registries, which allowed us to capture data for research and to quantify the burden of disease and the outcome more accurately; ${ }^{[18,19]}$ use of the data from these registries to further inform morbidity and mortality meetings and educational initiatives; and a surgical outreach programme (that has run for over a decade), designed to uplift surgical care in the rural hospitals of western KwaZulu-Natal. ${ }^{[20]}$

The grid structure helped in understanding the role of this latter programme and auditing its efficacy in transferring skills to the district hospitals. There are ongoing efforts to refine the process of care by developing burns teams, trauma teams and acute physiological support teams. ${ }^{[21,22]}$ The last introduction was an innovative attempt to provide improved care to surgical patients who were deemed to be too sick for the general ward but too well for the intensive care unit. ${ }^{[22]}$

Ongoing audit has revealed some successes and some failures. ${ }^{[23,24]}$ The grid enabled contextualisation of each research project and each intervention within the overarching system, and closure of the loop between research and strategy.

\section{Conclusion}

I have developed a grid structure that integrates the strategic planning process, the associated strategic planning tools, a model of the healthcare system, and the many quality metrics available to measure components of the system as they relate to acute care. As shown, each step in the strategic planning process and each individual quality metric can be placed within the grid to provide a system-wide overview. I believe that this grid will facilitate the development and implementation of successful quality improvement programmes in a variety of settings in the SA healthcare system.

1. Souba WW, Weitekamp MR, Mahon JF. Political strategy, business strategy, and the academic medical center: Linking theory and practice. J Surg Res 2001;100(1):1-10. [http://dx.doi.org/10.1006/ jsre.2001.6249]

2. Glickman SW, Bagget KA, Krubert CH, et al. Promoting quality: The health-care organization from a management perspective. Int J Qual Health Care 2007;19(3):341-348. [http://dx.doi.org/10.1093/ intqhe/mzm047]

3. Jacobs T, Shepherd J, Johnson G. Strengths, weaknesses, opportunities and threats (SWOT) analysis. In: Ambrosini V, Johnson G, Scholes K, eds. Exploring Techniques of Analysis and Evaluation in

Strategic Management. London: Prentice Hall, 1998:122-133.
Kaplan RS, Norton DP. The balanced scorecard - measures that drive performance. Harv Bus Rev Kaplan RS, Norto

1992;70(1):71-79.
5. Donabedian A. The quality of care. How can it be assessed? JAMA 1988;260(12):1743-1748. [http:// 5onabedian A. The quality of care. How
dx.doi.org/10.1001/jama.260.12.1743]

6. Mainz J. Defining and classifying clinical indicators for quality improvement. Int $J$ Qual Health Care 2003;15(6):523-530. [http://dx.doi.org/10.1093/intqhc/mzg081]

7. Clarke DL, Aldous C, Thomson SR. Assessing the gap between the burden of trauma in Sisonke District and the surgical capacity of the district hospitals: What are the implications for planning? Eur J Trauma Emerg Surg 2014;40(3):303-308. [http://dx.doi.org/10.1007/s00068-013-0369-0]

8. Clarke DL, Gouveia J, Thomson SR, Muckart DJ. Applying modern error theory to the problem of missed injuries in trauma. World J Surg 2008;32(6):1176-1182.

9. Clarke DL, Kong VY, Handley J, Aldous C. A concept paper: Using the outcomes of common surgical conditions as quality metrics to benchmark district surgical services in South Africa as part of a systemic quality improvement programme. S Afr J Surg 2013;51(3):84-86. [http://dx.doi.org/10.7196/SAJS.1476]

10. Alexander T, Fuller G, Hargovan P, Clarke DL, Muckart DI, Thomson SR. An audit of the quality of care of traumatic brain injury at a busy regional hospital in South Africa. S Afr J Surg 2009;47(4):120care of trauma

11. Stewart WW, Farina Z, Clarke DL, Thomson SR. Variations in levels of care within a hospital provided to acute trauma patients. S Afr J Surg 2011;49(4):194-198.

2. Clarke DL, Allorto NL, Thomson SR. An audit of failed non-operative management of abdominal stab wounds. Injury 2010;41(5):488-491. [http://dx.doi.org/10.1016/j.injury.2009.10.022]

3. Clarke DL, Aldous C, Thomson SR. The implications of the patterns of error associated with acute trauma care in rural hospitals in South Africa for quality improvement programs and trauma education. Injury 2013;45(1):285-288. [http://dx.doi.org/10.1016/j.injury.2013.04.011]

4. Allorto NL, Oosthuizen GV, Clarke DL, Muckart DJ. The spectrum and outcome of burns in a regional hospital in South Africa. Burns 2009;35(7):1004-1008. [http://dx.doi.org/10.1016/j.burns.2009.01.004]

15. Kong VY, van der Linde S, Handley J Aldous C Clarke DL. Quantifying the disparity in outco 2013;103(10):742-745. [http://dx.doi.org/10.7196/SAMJ.7109]

16. Aldous C, Searle R, Clarke DL. An error awareness program for junior doctors. African Journal of Health Professions Education 2014;6(2):161. [http://dx.doi.org/10.7196/AJHPE.350]

17. Clarke DL, Furlong H, Laing GL, Aldous C, Thomson SR. Using a structured morbidity and mortality meeting to understand the contribution of human error to adverse surgical events in a South African regional hospital. S Afr J Surg 2013;51(4):122-126. [http://dx.doi.org/10.7196/SAJS.1537]

8. Clarke DL, Aldous C. Surgical outreach in rural South Africa: Are we managing to impart surgical skills? S Afr Med J 2013;104(1):57-60. [http://dx.doi.org/10.7196/SAMJ.7252]

19. Laing GL, Bruce JL, Aldous C, Clarke DL. The design, construction and implementation of a computerized trauma registry in a developing South African metropolitan trauma service. Injury 2014;45(1):3-8. [http://dx.doi.org/10.1016/j.injury.2013.05.013] 
Table 4. Using the comprehensive structure for quality improvement programmes to contextualise a number of diverse research projects

\begin{tabular}{|c|c|c|c|c|}
\hline Vision & Quality metric & Quality metric & Quality metric & \\
\hline Mission & Inputs & Processes & Outcomes & \\
\hline $\begin{array}{l}\text { Analysis } \\
\text { SWOT } \\
\text { Strategic drift } \\
\text { Balanced scorecard }\end{array}$ & $\begin{array}{l}\text { Grid } 1 \\
\text { Assessing the gap between } \\
\text { the acute trauma workload } \\
\text { and the capacity of a single } \\
\text { rural health district in SA. } \\
\text { What are the implications for } \\
\text { systems planning? } \\
\text { A concept paper: using } \\
\text { the outcomes of common } \\
\text { surgical conditions as quality } \\
\text { metrics to benchmark district } \\
\text { surgical services in SA as } \\
\text { part of a systemic quality } \\
\text { improvement programme }{ }^{[8]} \\
\text { Applying modern error } \\
\text { theory to the problem of } \\
\text { missed injuries in trauma }\end{array}$ & $\begin{array}{l}\text { Grid } 2 \\
\text { An audit of the quality of care } \\
\text { of traumatic brain injury at a } \\
\text { busy regional hospital in } \mathrm{SA}^{[10]} \\
\text { Variations in levels of care } \\
\text { within a hospital provided to } \\
\text { acute trauma patients }{ }^{[1]}\end{array}$ & $\begin{array}{l}\text { Grid } 3 \\
\text { An audit of failed non- } \\
\text { operative management of } \\
\text { abdominal stab wounds }{ }^{[12]} \\
\text { The implications of } \\
\text { the patterns of error } \\
\text { associated with acute } \\
\text { trauma care in rural } \\
\text { hospitals in SA for quality } \\
\text { improvement programmes } \\
\text { and trauma education }{ }^{[13]} \\
\text { The spectrum and } \\
\text { outcome of burns in a } \\
\text { regional hospital in } \mathrm{SA}^{[14]} \\
\text { Quantifying the disparity } \\
\text { in outcome between urban } \\
\text { and rural patients with } \\
\text { acute appendicitis in } \mathrm{SA}^{[15]}\end{array}$ & Metrics \\
\hline $\begin{array}{l}\text { Synthesis and } \\
\text { implementation } \\
\text { Generic quality } \\
\text { improvement } \\
\text { strategies } \\
\text { Increase resources } \\
\text { Improve process }\end{array}$ & $\begin{array}{l}\text { Grid } 4 \\
\text { An educational programme } \\
\text { for error awareness in acute } \\
\text { trauma for junior doctors }{ }^{[6]} \\
\text { Using a structured morbidity } \\
\text { and mortality meeting to } \\
\text { understand the contribution of } \\
\text { human error to adverse surgical } \\
\text { events in an SA regional } \\
\text { hospital } \\
\text { Surgical outreach in rural SA: } \\
\text { are we managing to impart } \\
\text { surgical skills? }{ }^{\text {[18] }} \\
\text { The design, construction } \\
\text { and implementation of } \\
\text { a computerised trauma } \\
\text { registry in a developing } \\
\text { SA metropolitan trauma } \\
\text { service }{ }^{[19]} \\
\text { Development, } \\
\text { implementation and } \\
\text { evaluation of a hybrid } \\
\text { electronic medical record } \\
\text { system specifically designed } \\
\text { for a developing-world } \\
\text { surgical service } \\
\text { [20] }\end{array}$ & $\begin{array}{l}\text { Grid } 5 \\
\text { Tick-box admission forms } \\
\text { improve the quality of } \\
\text { documentation of surgical } \\
\text { emergencies, but have limited } \\
\text { impact on clinical behaviour }{ }^{[21]} \\
\text { The introduction of an acute } \\
\text { physiological support service } \\
\text { for surgical patients is an } \\
\text { effective error reduction } \\
\text { strategy }^{[22]}\end{array}$ & $\begin{array}{l}\text { Grid } 6 \\
\text { A multifaceted } \\
\text { quality improvement } \\
\text { programme results in } \\
\text { improved outcomes } \\
\text { for the selective non- } \\
\text { operative management of } \\
\text { penetrating abdominal } \\
\text { trauma in a developing } \\
\text { world trauma centre }{ }^{[23]} \\
\text { Challenges and merits of } \\
\text { improving burn care in } \\
\text { SA }^{[24]}\end{array}$ & $\begin{array}{l}\text { Develop } \\
\text { targeted quality } \\
\text { improvement } \\
\text { programmes }\end{array}$ \\
\hline Vision & Quality metric & Quality metric & Quality metric & \\
\hline
\end{tabular}

20. Laing GL, Bruce JL, Skinner DL, Allorto NL, Clarke DL, Aldous C. Development, implementation and evaluation of a hybrid electronic medical record system specifically designed for a developing world surgical service. World J Surg 2014;38(6):1388-1397. [http://dx.doi.org/10.1007/s00268-013world s

21. Laing GL, Bruce JL, Clarke DL. Tick-box admission forms improve the quality of documentation of surgical emergencies, but have limited impact on clinical behavior. S Afr Med J 2014;104(6):435-438. [http://dx.doi.org/10.7196/SAMJ.7673]

22. Clarke DL, Kong VY, Naidoo LC, Furlong H, Aldous C. The introduction of an acute physiological support service for surgical patients is an effective error reduction strategy. Int J Surg 2013;11(9):989992. [http://dx.doi.org/10.1016/j.ijsu.2013.06.003]
23. Laing GL, Skinner DL, Bruce JL, Bekker W, Oosthuizen GV, Clarke DL. A multi faceted quality improvement programme results in improved outcomes for the selective non-operative management of penetrating abdominal trauma in a developing world trauma centre. Injury 2014;45(1):327-332. [http://dx.doi.org/10.1016/j.injury.2013.08.021]

24. Allorto N, Clarke DL. Merits and challenges in the development of a dedicated burn service at a regional hospital in South Africa. Published online 20 August 2014. http://dx.doi.org/10.1016/j. burns.2014.07.021

Accepted 18 August 2014. 